\title{
PENGEMBANGAN INSTRUMEN PENILAIAN KUALITAS KONSUMSI PANGAN PADA RUMAH TANGGA MISKIN DI INDONESIA
}

\author{
Yayuk Farida Baliwati' ${ }^{1}$, Dodik Briawan ${ }^{1}$, Vitria Melani ${ }^{2}$ \\ 1Dosen Program Studi Gizi Masyarakat, Fakultas Ekologi Manusia (FEMA), \\ Institut Pertanian Bogor (IPB), Bogor \\ 2Program Studi Gizi Masyarakat, Fakultas Ekologi Manusia (FEMA), \\ Institut Pertanian Bogor (IPB), Bogor \\ yayuk_gm@yahoo.com
}

\section{ABSTRAK}

Rumah tangga miskin merupakan kelompok yang berisiko mengalami rawan pangan karena keterbatasan akses secara ekonomi maupun secara fisik. Keragaman konsumsi pangan rumah tangga diduga mampu dijadikan sebagai indikator rawan pangan. Salah satu metode sederhana untuk menilai keragaman konsumsi pangan rumah tangga adalah Household Dietary Diversity Score (HDDS). HDDS mencerminkan kemampuan ekonomi rumah tangga dalam memperoleh berbagai jenis pangan. Tujuan penelitian ini adalah mengetahui kualitas konsumsi pangan rumah tangga miskin menggunakan skor HDDS dan validasi HDDS sebagai metode alternatif dalam mendeteksi kejadian rawan pangan pada rumah tangga miskin. Penelitian dilaksanakan di Kabupaten Bogor pada bulan Mei-Oktober 2013. Data yang dikumpulkan meliputi karakteristik rumah tangga dan konsumsi pangan di dalam rumah yang dikumpulkan menggunakan metode recall 1 × 24 jam. Wawancara dilakukan terhadap ibu yang memiliki peran penting dalam menentukan konsumsi pangan rumah tangga. Hasil analisis menunjukkan skor HDDS yang tinggi di seluruh lokasi penelitian (skor 6-12), yang berarti konsumsi pangan rumah tangga cukup beragam, namun secara kuantitas asupan energi dan proteinnya masih rendah. Terdapat 61,3 persen rumah tangga tergolong kelompok defisit energi tingkat berat (<70\% Tingkat Kecukupan Energi). Uji sensitivitas (Se) menunjukkan HDDS sensitif 26,95 persen untuk mendeteksi kejadian rawan pangan pada rumah tangga miskin. Hasil uji spesifisitas (Sp) menunjukkan HDDS spesifik 85,16 persen untuk mendeteksi tahan pangan pada rumah tangga miskin. Setelah dilakukan modifikasi dengan mengategorikan kelompok pangan berdasarkan fungsi gizi, nilai Se meningkat menjadi 91,04 persen dan nilai Sp menurun menjadi 35,61 persen. Hasil ini menunjukkan bahwa HDDS modifikasi memiliki sensitivitas yang baik untuk mendeteksi kejadian rawan pangan pada rumah tangga miskin.

Kata kunci: HDDS, keragaman konsumsi pangan, rawan pangan, sensitivitas, spesifisitas

\section{ABSTRACT}

\section{THE DEVELOPMENT OF DIETARY QUALITY ASSESSMENT INSTRUMENT IN POOR HOUSEHOLDS IN INDONESIA}

Poor households were a risk group of food insecurity due to limited of economic and physic access. Household dietary diversity was predicted can be used as an indicator of food insecurity. Household Dietary Diversity Score (HDDS) is the method used to assess the dietary diversity. The purpose of this study was to determine dietary quality of poor households using HDDS scores and to test HDDS as an alternative method to identify food insecurity in poor households in Indonesia. Data collected from May until October 2013 included household characteristics and household dietary intake at home using 1 x 24hour recall. The results showed a high HDDS scores (scores 6-12) across the study sites, which means, household food consumption is quite diverse. In terms of quantity, energy and protein intakes of household members remained low despite HDDS scores indicated that consumption had been diverse. There were 61.3 per cent households which classified as severe level of energy deficit group $(<70 \%)$. The test of the sensitivity (Se) and specificity (Sp) showed that HDDS only 26,95per cent sensitive to identify food insecurity in poor households and $85,16 \%$ specific to identify food security in poor households. After modifications by grouping of food based on nutritional function, the Se values increased to 91.04per cent and Sp values decreased to 35.61 per cent. These results indicated that the modified HDDS were able to identify food insecurity in poor households.

Keywords: HDDS, dietary diversity, food insecurity, sensitivity, specificity 


\section{PENDAHULUAN}

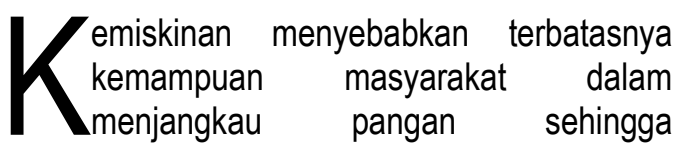
meningkatkan risiko terjadinya rawan pangan. Di Indonesia, rumah tangga miskin merupakan salah satu indikator yang digunakan dalam deteksi dini kejadian rawan pangan melalui Sistem Kewaspadaan Pangan dan Gizi. ${ }^{1}$ Kejadian rawan pangan merupakan akibat langsung yang ditimbulkan akibat rendahnya konsumsi pangan.

Konsumsi pangan yang baik ditunjukkan oleh kuantitas dan kualitas pangan yang baik. Kuantitas konsumsi pangan ditunjukkan melalui tingkat kecukupan gizi terutama energi dan protein. Tingkat kecukupan energi telah lama digunakan sebagai gold standard untuk mendeteksi kejadian rawan pangan. ${ }^{2}$ Tingkat kecukupan energi yang kurang dari 70persen mengimplikasikan terjadinya rawan pangan. ${ }^{3}$ Kualitas konsumsi pangan digambarkan melalui keragaman konsumsi pangan.

Keragaman konsumsi pangan telah lama diketahui sebagai salah satu bagian penting dari konsumsi pangan yang berkualitas. Keragaman konsumsi pangan di tingkat rumah tangga dipengaruhi oleh berbagai faktor seperti pengetahuan gizi, ketersediaan pangan, jumlah anggota rumah tangga, dan sosioekonomi. ${ }^{4}$ Keragaman konsumsi pangan juga dapat digunakan sebagai indikator rawan pangan. ${ }^{5}$

Salah satu metode yang digunakan dalam mengetahui keragaman konsumsi pangan adalah Household Dietary Diversity Score (HDDS). HDDS mencerminkan kemampuan ekonomi rumah tangga dalam memperoleh berbagai jenis bahan pangan. ${ }^{6}$ Instrumen sederhana ini dikembangkan oleh Food and Agriculture Organization $(\mathrm{FAO})^{5}$ dan telah digunakan di berbagai negara di Afrika, salah satunya di Mozambik pada tahun 2007 sebagai metode penilaian keragaman konsumsi pangan yang efektif. ${ }^{7}$

Belum terdapat penelitian mengenai validasi metode HDDS sebagai instrumen yang mudah dalam menilai kualitas konsumsi pangan dan sebagai metode alternatif dalam mendeteksi kejadian rawan pangan pada rumah tangga miskin di Indonesia. Sehingga perlu dilakukan uji coba terhadap metode HDDS tersebut agar dapat diterapkan di Indonesia sebagai metode penilaian konsumsi pangan rumah tangga yang efektif dan efisien.

Tujuan dari penelitian ini adalah mengetahui kualitas konsumsi pangan rumah tangga miskin menggunakan skor HDDS dan validasi HDDS sebagai metode alternatif dalam mengidentifikasi kejadian rawan pangan pada rumah tangga miskin.

\section{METODE PENELITIAN}

\section{Desain, Lokasi, dan Waktu Penelitian}

Desain penelitian yang digunakan adalah cross sectional study. Lokasi penelitian dipilih secara purposive pada empat wilayah di Kabupaten Bogor yang diduga mampu mewakili keragaman agroekologi Indonesia, yaitu, Kecamatan Gunung Putri, Cibinong, Cigudeg, dan Ciawi. Penelitian dilakukan dari bulan Mei sampai Oktober 2013.

\section{Jumlah dan Cara Pengambilan Rumah Tangga Miskin}

Kriteria inklusi Rumah Tangga miskin (1) termasuk ke dalam kelompok rumah tangga miskin; (2) mayoritas anggota rumah tangga selalu makan di rumah; dan (3) pekerjaan utama kepala rumah tangga sesuai dengan karakteristik masing-masing kecamatan yaitu sebagai buruh pabrik di kecamatan Gunung Putri, buruh/jasa di Cibinong yang mewakili wilayah kumuh, petani padi di kecamatan Cigudeg, dan petani sayur dan hortikultura di kecamatan Ciawi. Jumlah rumah tangga miskin minimal yang akan diambil berdasarkan kriteria inklusi dihitung dengan menggunakan rumus Lemeshow. ${ }^{8}$ Berdasarkan perhitungan diperoleh jumlah rumah tangga miskin minimal sebesar 95 rumah tangga per kecamatan. Pada penelitian ini akan diambil 105 rumah tangga dari setiap kecamatan, sehingga total rumah tangga yang digunakan adalah 420 rumah tangga. 
Tabel 1

Kelompok Pangan untuk Menentukan Skor HDDS

\begin{tabular}{llll}
\hline No & Kelompok pangan & No & Kelompok pangan \\
\hline 1 & Serealia & 7 & Ikan dan makanan laut lainnya \\
2 & Umbi-umbian & 8 & Polong-polongan dan kacang-kacangan \\
3 & Sayur-sayuran & 9 & Susu dan olahannya \\
4 & Buah-buahan & 10 & Minyak dan lemak \\
5 & Daging dan olahannya & 11 & Gula dan pemanis \\
6 & Telur & 12 & Bumbu, rempah, dan minuman \\
\hline
\end{tabular}

\section{Jenis dan Cara Pengumpulan Data}

Data yang dikumpulkan merupakan data primer yang meliputi data karakteristik rumah tangga dan konsumsi pangan selama 1x24 jam yang telah lalu. Data karakteristik rumah tangga meliputi jumlah anggota rumah tangga, jenis kelamin, usia, tingkat pendidikan, pekerjaan, dan kisaran penghasilan kepala rumah tangga per bulan. Data konsumsi pangan diperoleh melalui recall (mengingat kembali) konsumsi pangan selama 1 × 24 jam. Wawancara dilakukan terhadap ibu rumah tangga yang memiliki peran penting dalam menentukan menu konsumsi pangan rumah tangga.

\section{Pengolahan dan Analisis Data}

Data yang terkumpul dianalisis secara deskriptif dan statistika inferensia. Program komputer yang digunakan adalah Microsoft Excel 2007 dan SPSS version 16.0 for windows. Proses pengolahan data meliputi entry, coding, editing, dan analisis data.

Kualitas konsumsi pangan dapat diketahui dari berbagai jenis makanan yang dikonsumsi pada tingkat rumah tangga. Pada perhitungan skor HDDS, jenis pangan yang dikonsumsi rumah tangga dikelompokkan ke dalam 12 kelompok pangan (Tabel 1). ${ }^{6}$

Pemberian skor dilakukan dengan memberikan skor 1 jika rumah tangga mengonsumsi dan skor 0 jika tidak mengonsumsi salah satu jenis pangan yang terdapat dalam kelompok pangan yang sudah ditetapkan oleh FAO. ${ }^{10}$ Keragaman konsumsi pangan berdasarkan HDDS dikelompokkan ke dalam tiga kategori yaitu rendah jika konsumsi $\leq 3$ jenis bahan pangan, sedang jika konsumsi 4-5 jenis bahan pangan, dan tinggi jika konsumsi $\geq 6$ jenis bahan pangan.

Penilaian kualitas konsumsi pangan rumah tangga ini dikombinasikan dengan metode kuantitatif penilaian konsumsi pangan rumah tangga. Sehingga dalam pelaksanaannya tidak hanya didata jenis pangan yang dikonsumsi saja, tetapi juga jumlah pangan yang dikonsumsi dalam satuan ukuran rumah tangga (URT) yang selanjutnya dikonversi ke dalam satuan gram. Data ini selanjutnya dikonversi lagi ke dalam energi dan protein dengan menggunakan Daftar Komposisi Bahan Makanan. ${ }^{3}$ Konversi dihitung menggunakan rumus sebagai berikut ini:

$$
K G i j=(B j / 100) \times G i j \times(B D D j / 100)
$$

Keterangan:

KGij= Kandungan zat gizi -i dalam bahan makanan-j; BJ= Berat bahan makanan j yang dikonsumsi (gram); Gij= Kandungan zat gizi dalam 100 gram BDD bahan makanan -j; $\mathrm{BDD}=$ Persen bahan makanan $\mathrm{j}$ yang dapat dimakan (\%BDD)

Tingkat kecukupan energi dan protein dihitung dengan membandingkan konsumsi energi dan protein rumah tangga dengan nilai Angka Kecukupan Energi (AKE) dan Angka Kecukupan Protein (AKP) rumah tangga yang dinyatakan dalam persen. 
Tabel 2

Sensitivitas Sensitivitas (Se) dan Spesifisitas (Sp) HDDS terhadap TKE

\begin{tabular}{lccc}
\hline \multirow{2}{*}{ HDDS } & \multicolumn{2}{c}{ Tingkat Kecukupan Energi (TKE) } & \\
\cline { 2 - 3 } & $\begin{array}{c}\text { Rendah } \\
(<70 \% \text { AKE) }\end{array}$ & $\begin{array}{c}\text { Tinggi } \\
(\geq 70 \% \text { AKE) }\end{array}$ & \\
\hline Rendah (0-5) & TP & FP & TP + FP \\
Tinggi (6-12) & FN & TN & FN + TN \\
Jumlah & TP + FN & FP + TN & Total \\
\hline
\end{tabular}

Keterangan: $\mathrm{TP}=$ true positif; $\mathrm{FP}=$ false positif; $\mathrm{FN}=$ false negatif; $\mathrm{TN}=$ true negatif

Klasifikasi tingkat kecukupan energi (TKE) dan protein didasarkan pada kategori Depkes tahun 1996 yaitu defisit tingkat berat $(<70 \%)$, defisit tingkat sedang (70-79\%), defisit tingkat ringan $(80-89 \%)$, normal $(90-119 \%)$, dan kelebihan $(\geq 120 \%)$.

Data kualitas konsumsi pangan rumah tangga berdasarkan HDDS dan kuantitas konsumsi pangan rumah tangga berdasarkan TKE dianalisis lebih lanjut dalam analisis validasi. Analisis ini bertujuan untuk membandingkan ukuran kualitatif (HDDS) dengan ukuran kuantitatif (TKE) konsumsi pangan rumah tangga yang umum digunakan dalam menentukan rumah tangga rawan pangan.

Uji sensitivitas (Se) HDDS dilakukan untuk menilai kemampuan HDDS dalam mengidentifikasi kejadian rawan pangan pada rumah tangga miskin yang juga dikatakan rawan pangan berdasarkan TKE. Uji spesifisitas (Sp) HDDS dilakukan untuk menilai kemampuan HDDS dalam mengidentifikasi kejadian tahan pangan pada rumah tangga miskin yang juga dikatakan tahan pangan berdasarkan TKE.

Secara kualitatif, konsumsi pangan dikatakan tidak beragam jika mengonsumi kurang dari enam jenis pangan dan beragam jika mengonsumsi paling sedikit enam jenis pangan. ${ }^{10}$ Secara kuantitatif, rumah tangga dikatakan rawan pangan jika konsumsi energi kurang dari $70 \%$ AKE. Tabulasi silang dalam menentukan Se dan Sp mengacu pada Maxwe//11 dan IFPRI ${ }^{12}$ yang disajikan pada Tabel 2.

Pengukuran Se dan Sp dilakukan dengan menggunakan rumus. Sensitivitas merupakan hasil pembagian nilai true positif dengan nilai true positif dan nilai false negatif. Sedangkan spesifitas merupakan hasil pembagian nilai true negatif dengan nilai false positif dan nilai true negatif.

\section{HASIL}

\section{Sosio Ekonomi Rumah Tangga}

Rumah tangga contoh yang digunakan pada penelitian ini merupakan rumah tangga yang tergolong miskin, yang diduga memiliki risiko rawan pangan yang lebih tinggi. Jumlah rumah tangga yang dianalisis setelah dilakukan cleaning adalah sebanyak 411 rumah tangga. Berdasarkan hasil analisis tersebut diketahui rata-rata jumlah anggota rumah adalah empat orang.

Rata-rata usia kepala dan ibu rumah tangga berada pada kisaran usia 30-49 tahun, yang termasuk ke dalam kelompok usia produktif. Dari segi tingkat pendidikan kepala dan ibu rumah tangga, mayoritas berpendidikan Sekolah Dasar (SD) yaitu 44,5persen pada kepala rumah tangga dan 51,3 persen pada ibu rumah tangga. Jika dilihat per wilayah penelitian, mayoritas kepala rumah tangga di Desa Wanaherang dan Kelurahan Nanggewer yang merupakan desa perkotaan adalah berpendidikan Sekolah Menengah Atas (SMA) $(62 \%)$, sedangkan di wilayah desa perdesaan, Desa Sukamaju dan Citapen, mayoritas kepala rumah tangga berpendidikan SD $(77 \%)$. Hal serupa juga terlihat pada pendidikan ibu rumah tangga di kedua wilayah tersebut. Namun untuk wilayah Desa Wanaherang dan Kelurahan Nanggewer, jumlah ibu rumah tangga lulusan Sekolah Menengah Pertama (SMP) dan SMA tidak jauh berbeda (40\%). Berdasarkan tingkat penghasilan kepala rumah tangga, lebih dari 40\% kepala rumah tangga berpenghasilan tidak lebih dari Rp 800.000 per bulan. Angka ini masih jauh dari Upah Minimum Regional (UMR) Kabupaten Bogor tahun 2013 yaitu Rp 2.002.000,-- 
Tabel 3

Kategori keragaman konsumsi pangan berdasarkan skor HDDS

\begin{tabular}{lccc}
\hline $\begin{array}{c}\text { Kategori } \\
\text { Wilayah }\end{array}$ & $\begin{array}{c}\text { Rendah } \\
(\leq 3 \text { jenis })\end{array}$ & $\begin{array}{c}\text { Sedang } \\
(4-5 \text { jenis })\end{array}$ & $\begin{array}{c}\text { Tinggi } \\
(\geq 6 \text { jenis })\end{array}$ \\
\hline Total & 3,6 & 18,7 & 77,6 \\
Desa Wanaherang & 4,0 & 12,9 & 83,2 \\
Desa Nanggewer & 6,8 & 28,2 & 65,0 \\
Desa Sukamaju & 1,9 & 24,0 & 74,0 \\
Desa Citapen & 1,9 & 9,7 & 88,3 \\
\hline
\end{tabular}

Tingkat pendidikan yang rendah, didukung dengan tingkat penghasilan yang rendah berpengaruh terhadap kebiasaan makan seharihari. Definisi makan bagi kelompok seperti ini bukanlah yang sehat dan bergizi, namun makan makanan yang mengenyangkan tanpa melihat nilai gizi dari makanan tersebut. Hal tersebut diduga dapat menjadi faktor risiko terjadinya rawan pangan.

\section{Keragaman Konsumsi Pangan Rumah Tangga Berdasarkan Skor HDDS}

Konsumsi pangan yang beragam diketahui sebagai elemen utama penentu kualitas diet. ${ }^{13}$ Pola konsumsi pangan dan gizi rumah tangga dipengaruhi oleh kondisi ekonomi, sosial, dan budaya masyarakat

Berdasarkan Tabel 3, terlihat bahwa keragaman konsumsi pangan di ke empat wilayah tergolong tinggi yaitu sebesar 77,6 persen di total wilayah penelitian. Desa yang memiliki tingkat keragaman konsumsi pangan yang paling tinggi adalah Desa Citapen yaitu sebesar 88,3 persen. Salah satu faktor pendukung tingginya keragaman konsumsi pangan di wilayah tersebut adalah akses fisik yang mudah terhadap beberapa kelompok pangan, seperti serealia dan sayuran. Faktor lainnya yang diduga mempengaruhi skor HDDS adalah pekerjaan kepala rumah tangga sebagai buruh tani yang sehari-harinya bekerja di sekitar rumah, sehingga untuk makan setiap hari juga dilakukan di rumah. Konsep HDDS yang hanya melihat pangan yang disiapkan dan dikonsumsi di rumah mendukung tingginya skor HDDS di wilayah tersebut.
Desa yang memiliki tingkat keragaman tertinggi kedua adalah Desa Wanaherang. Berbeda dengan Desa Citapen, faktor pendukung tingginya skor HDDS adalah kemampuan ekonomi rumah tangga. Jika dihubungkan dengan tingkat pendapatan, lebih dari 80 persen kepala rumah tangga di Desa Wanaherang berpenghasilan lebih dari Rp 1.800.000,- per bulan. Oleh karena itu, daya beli terhadap pangan relatif lebih tinggi. Tingkat keragaman konsumsi pangan di Desa Sukamaju berada di bawah Desa Wanaherang. Meskipun Desa Sukamaju merupakan daerah pertanian, namun akses ekonomi dan fisik rumah tangga terhadap pangan dari luar relatif rendah. Hal ini didukung dengan data dari desa tentang penerima Bantuan Langsung Sementara Masyarakat (BLSM) yang cukup banyak yaitu sebanyak 448 rumah tangga di desa tersebut. Keragaman konsumsi pangan yang paling rendah adalah di Kelurahan Nanggewer. Mayoritas kepala rumah tangga di wilayah padat penduduk ini bekerja sebagai buruh pabrik dan supir angkutan umum. Oleh karena itu, kebanyakan dari mereka tidak makan di rumah, sehingga skor HDDS untuk wilayah ini lebih rendah. Jika dilihat dari akses pangan, penduduk di desa ini memiliki akses ekonomi dan akses fisik yang baik karena terletak di perkotaan.

\section{Tingkat Kecukupan Energi dan Protein Rumah Tangga}

Tingkat Kecukupan Energi (TKE ) dan Protein (TKP) rumah tangga dihitung untuk melihat hubungan antara kuantitas dan kualitas konsumsi rumah tangga. 
Tabel 4

Klasifikasi Tingkat Kecukupan Energi di Rumah Tangga

\begin{tabular}{lccccc}
\hline & \multicolumn{5}{c}{ Klasifikasi Tingkat Kecukupan Energi } \\
\cline { 2 - 6 } Wilayah & $\begin{array}{c}\text { Defisit } \\
\text { tingkat berat } \\
(<70 \%)\end{array}$ & $\begin{array}{c}\text { Defisit } \\
\text { tingkat } \\
\text { sedang } \\
(70-79 \%)\end{array}$ & $\begin{array}{c}\text { Defisit } \\
\text { tingkat } \\
\text { ringan } \\
(80-89 \%)\end{array}$ & $\begin{array}{c}\text { Normal } \\
(90-119 \%)\end{array}$ & $\begin{array}{c}\text { Kelebihan } \\
(\geq 120 \%)\end{array}$ \\
\hline Wanaherang & 55,4 & 12,9 & 10,9 & 14,9 & 5,9 \\
Nanggewer & 62,1 & 9,7 & 7,8 & 13,6 & 6,8 \\
Sukamaju & 68,3 & 11,5 & 8,7 & 10,6 & 1,0 \\
Citapen & 59,2 & 14,6 & 6,8 & 15,5 & 3,9 \\
\hline
\end{tabular}

Tabel 5

Klasifikasi Tingkat Kecukupan Protein di Rumah Tangga

\begin{tabular}{lccccc}
\hline Wilayah & \multicolumn{5}{c}{ Klasifikasi Tingkat Kecukupan Protein } \\
\cline { 2 - 6 } & $\begin{array}{c}\text { Defisit } \\
\text { tingkat berat } \\
(<70 \%)\end{array}$ & $\begin{array}{c}\text { Defisit } \\
\text { tingkat } \\
\text { sedang } \\
(70-79 \%)\end{array}$ & $\begin{array}{c}\text { Defisit tingkat } \\
\text { ringan } \\
(80-89 \%)\end{array}$ & $\begin{array}{c}\text { Normal } \\
(90-119 \%)\end{array}$ & $\begin{array}{c}\text { Kelebihan } \\
(\geq 120 \%)\end{array}$ \\
\hline Wanaherang & 45,5 & 8,9 & 12,9 & 18,8 & 13,9 \\
Nanggewer & 60,2 & 7,8 & 9,7 & 11,7 & 10,7 \\
Sukamaju & 62,5 & 10,6 & 9,6 & 15,4 & 1,9 \\
Citapen & 60,2 & 15,5 & 6,8 & 12,6 & 4,9 \\
\hline
\end{tabular}

Berdasarkan Tabel 4 terlihat bahwa 61,3 persen dari total rumah tangga miskin tergolong kelompok defisit energi tingkat berat $(<70 \%)$ yaitu rata-rata konsumsi energi rumah tangga 5286, 22 kkal dengan rata-rata jumlah anggota rumah tangga empat orang. Desa Sukamaju merupakan wilayah dengan persentase defisit tingkat berat tertinggi yaitu 68,3 persen. Tiga wilayah lainnya juga memiliki angka defisit tingkat berat yang tinggi yaitu lebih dari 50 persen. Berdasarkan data tersebut, keempat wilayah dapat dikategorikan sebagai daerah rawan pangan.

Jika dilihat dari Tingkat Kecukupan Protein (TKP) yang disajikan pada Tabel 5, sebanyak 57,2 persen rumah tangga contoh tergolong defisit berat. Secara kuantitas, asupan energi dan protein rumah tangga masih rendah meskipun skor HDDS menunjukkan konsumsi yang sudah beragam. Berdasarkan penelitian ini, diperoleh hasil bahwa TKE dan TKP berbanding terbalik dengan skor HDDS. Hal ini diduga karena pemberian skor HDDS tidak memperhitungkan kontribusi zat gizi sesuai dengan fungsinya yaitu sebagai sumber energi, pembangun dan pengatur. Sehingga skor yang diperoleh meskipun tinggi, dapat saja berasal dari kelompok pangan dengan fungsi yang sama. Oleh karena itu, perlu dilakukan modifikasi metode HDDS agar dapat digunakan sebagai metode kualitatif yang mampu diterapkan di Indonesia.

\section{Validasi Metode HDDS}

Validasi metode HDDS dilakukan secara kuantitatif dengan menghitung nilai Sensitivitas (Se) dan Spesifisitas (Sp). Tujuannya adalah mengukur validasi metode HDDS dalam mengidentifikasi kejadian rawan pangan pada rumah tangga miskin berdasarkan Tingkat Kecukupan Energi (TKE). Pada analisis ini, yang digunakan sebagai benchmark adalah TKE dengan cut off point $<70$ persen (rawan pangan). Hasil perhitungan nilai Se dan Sp dari metode HDDS dengan benchmark disajikan pada Tabel 6. 
Tabel 6

Sebaran skor HDDS dengan benchmark Tingkat Kecukupan Energi (TKE)

\begin{tabular}{lccc}
\hline \multirow{2}{*}{ HDDS } & \multicolumn{2}{c}{ Tingkat Kecukupan Energi } & \\
\cline { 2 - 3 } & $\begin{array}{c}\text { Rendah } \\
(<70 \% \text { AKE })\end{array}$ & $\begin{array}{c}\text { Tingi } \\
(\geq 70 \% \text { AKE })\end{array}$ & \\
\hline Rendah $(0-5)$ & 69 & 23 & 92 \\
Tinggi $(6-12)$ & 187 & 132 & 319 \\
Jumlah & 256 & 155 & 411 \\
\hline
\end{tabular}

Tabel 7

Pengkategorian Kelompok Pangan untuk Modifikasi Skor HDDS

\begin{tabular}{|c|c|c|c|}
\hline $\begin{array}{l}\text { Kategori Pangan } \\
\text { Berdasarkan } \\
\text { Sumber Zat Gizi }\end{array}$ & $\begin{array}{l}\text { Kelompok Pangan HDDS } \\
\text { (16 kelompok pangan) }\end{array}$ & Skor & $\begin{array}{l}\text { Skor } \\
\text { Maks }\end{array}$ \\
\hline 1. Sumber karbohidrat & $\begin{array}{l}\text { Serealia } \\
\text { Umbi-umbian } \\
\text { Gula dan pemanis }\end{array}$ & $\begin{array}{l}0=\text { tidak konsumsi } \\
1=\text { berasal dari } 1 \text { kelompok pangan } \\
2=\text { berasal dari } \geq 2 \text { kelompok pangan }\end{array}$ & 2 \\
\hline 2. Sumber lemak & Minyak dan lemak & $\begin{array}{l}0=\text { tidak konsumsi } \\
1=\text { konsumsi } 1 \text { jenis } \\
2=\text { konsumsi } \geq 2 \text { jenis }\end{array}$ & 2 \\
\hline $\begin{array}{l}\text { 3. Sumber protein } \\
\text { hewani }\end{array}$ & $\begin{array}{l}\text { Daging-dagingan } \\
\text { Jeroan } \\
\text { Telur } \\
\text { Ikan dan makanan laut } \\
\text { lainnya } \\
\text { Susu dan olahannya }\end{array}$ & $\begin{array}{l}0=\text { tidak konsumsi } \\
1=\text { berasal dari } 1 \text { kelompok pangan } \\
2=\text { berasal dari } \geq 2 \text { kelompok pangan }\end{array}$ & 2 \\
\hline $\begin{array}{l}\text { 4. Sumber protein } \\
\text { nabati }\end{array}$ & Kacang-kacangan & $\begin{array}{l}0=\text { tidak konsumsi } \\
1=\text { konsumsi } 1 \text { jenis } \\
2=\text { konsumsi } \geq 2 \text { jenis }\end{array}$ & 2 \\
\hline $\begin{array}{l}\text { 5. Sumber vitamin } \\
\text { dan mineral }\end{array}$ & $\begin{array}{l}\text { Sayur sumber vitamin A } \\
\text { Sayuran hijau } \\
\text { Sayuran lainnya } \\
\text { Buah sumber vitamin A } \\
\text { Buah lainnya }\end{array}$ & $\begin{array}{l}0=\text { tidak konsumsi } \\
1=\text { berasal dari } 1 \text { kelompok pangan } \\
2=\text { berasal dari } \geq 2 \text { kelompok pangan }\end{array}$ & 2 \\
\hline 6. Lain-lain & Bumbu dan minuman jadi & $\begin{array}{l}0=\text { tidak konsumsi } \\
1=\text { konsumsi } 1 \text { jenis } \\
2=\text { konsumsi } \geq 2 \text { jenis }\end{array}$ & 2 \\
\hline \multicolumn{3}{|c|}{ Total } & 12 \\
\hline
\end{tabular}

$$
\begin{aligned}
& \text { Sensitivitas }=\frac{69}{(69+187)}=26,95 \\
& \text { Spesifisitas }=\frac{132}{(132+23)}=85,16
\end{aligned}
$$

Berdasarkan perhitungan di atas diketanuı bahwa HDDS hanya sensitif 26,95 persen mendeteksi kejadian rawan pangan pada rumah tangga miskin. Hasil uji Spesifisitas (Sp) menunjukkan HDDS hanya Spesifik (Se) 85,16 persen untuk mendeteksi kejadian tahan pangan pada rumah tangga miskin. Sehingga, perlu dilakukan modifikasi metode HDDS untuk meningkatkan nilai Se dan Sp. 


\section{BAHASAN}

\section{Modifikasi Skor HDDS}

Penentuan skor pada HDDS yang ditetapkan oleh FAO tidak mempertimbangkan fungsi zat gizi yang dikonsumsi. Sebagai contoh, serealia dan umbi-umbian memiliki fungsi yang sama sebagai sumber karbohidrat (energi). Namun dalam pemberian skor keduanya berada pada kelompok yang berbeda. Sehingga, skor yang tinggi bisa saja berasal dari sumber pangan dengan fungsi zat gizi yang sama. Modifikasi dilakukan dengan mengkategorikan kelompok pangan dengan fungsi gizi yang sama ke dalam satu kategori.

Pemberian skor dilakukan dengan memberikan skor 0 jika rumah tangga sama sekali tidak mengkonsumsi kelompok pangan, skor 1 jika rumah tangga mengkonsumsi salah satu kelompok pangan, dan skor 2 jika rumah tangga mengkonsumsi seluruh kelompok pangan pada masing-masing kategori. Keragaman konsumsi pangan berdasarkan skor HDDS modifikasi dikelompokkan ke dalam dua kategori yaitu rendah jika skor $\leq 8$ dan tinggi jika skor $\geq 9$. Hasil modifikasi ini memberikan nilai sensitivitas (Se) yang tinggi yaitu $91.04 \%$, dan nilai spesifisitas $(\mathrm{Sp})$ yang rendah yaitu 35,61 persen. Nilai ini menunjukkan bahwa metode HDDS modifikasi sensitif sebesar 91,04 persen untuk mendeteksi kejadian rawan pangan pada rumah tangga miskin dan hanya spesifik 35,61persen untuk mendeteksi kejadian tahan pangan pada rumah tangga miskin.

\section{SIMPULAN DAN SARAN}

\section{Simpulan}

Berdasarkan skor HDDS, rumah tangga di keempat wilayah penelitian menunjukkan keragaman konsumsi pangan yang tinggi (skor 6-12). Namun, prevalensi rumah tangga defisit energi dan protein yang tergolong defisit berat ( $<70$ persen ) masih sangat tinggi yaitu di atas 50 persen. Uji sensitivitas (Se) dan spesifisitas (Sp) menunjukkan metode HDDS hanya sensitif 26,95 persen mendeteksi kejadian rawan pangan pada rumah tangga miskin dan hanya spesifik 85,16 persen untuk mendeteksi kejadian tahan pangan pada rumah tangga miskin. Modifikasi HDDS dilakukan dengan memperhitungkan fungsi zat gizi di dalam penentuan skor. Skor berkisar dari 0-2 untuk setiap kategori dan 0-12 untuk total skor. Hasil modifikasi menunjukkan HDDS sensitif 91,04persen untuk mendeteksi kejadian rawan pangan pada rumah tangga miskin dan hanya spesifik 35,61persen mendeteksi kejadian tahan pangan pada rumah tangga miskin.

\section{Saran}

HDDS modifikasi dapat digunakan sebagai metode alternatif dalam mendeteksi kejadian rawan pangan rumah tangga miskin di Indonesia.

\section{RUJUKAN}

1. Ariani M, Saliem HP, Hardono GS, Purwantini TB. Analisis wilayah rawan pangan dan rawan gizi kronis serta alternatif penanggulangannya. Jakarta: Deptan, 2006.

2. Maxwell D, Coates J, Vaitla B. How do Different Indicators of Household Food Security Compare? Empirical Evidence from Tigray. Boston: Tufts University, 2013.

3. Departemen Kesehatan. 13 Pesan Dasar Gizi Seimbang. Jakarta: Depkes, 1996.

4. Hardinsyah. Review Faktor Determinan Keragaman Konsumsi Pangan. Jurnal Gizi dan Pangan 2007; 2(2): 55-74.

5. Swindale A, Bilinsky P. Household Dietary Diversity Score (HDDS) for Measurementof Household Food Access: Indicator Guide. Washington: FANTA, 2005.

6. Kennedy G, Ballard T, Dop MC. Guidelines for Measuring Household and Individual Dietary Diversity. Rome: FAO, 2013.

7. Food and Agricultur Organization. Report On Use of The Household Food Insecurity Access Scale and Household Dietary Diversity Score in Two Survey Rpunds in Manica and Sofala Provinces Mozambique 2006-2007. Rome, 2008

8. Lemeshow S, Hosmer DW, Klar J, Lwangan SK. Adequacy Of Sample Size In Health Studies. New York: World Health Organization, 1990

9. Badan Pusat Statistik. Kabupaten Bogor Dalam Angka 2012. Bogor: BPS, 2012.

10. Kennedy G, Ballard T, Dop MC. Guidelines for Measuring Household and Individual Dietary Diversity. Rome: FAO, 2011. 
11. Maxwell D, Ahiadeke C, Levin L, ArmarKlemesu M, Zakariah S, Lamptey GM. Alternative food security indicators: revisiting the frequency and severity of coping strategies. Food Policy 1999; 24(4): 411-429.

12. International Food Policy Research Institute. Validation of Food Frequency and
Dietary Diversity as Proxy Indicators of Household Food Security. Italy: IFPRI, 2008.

13. Ruel MT. Operationalizing Dietary Diversity: A Review of Measurement Issuesand Research Priorities. Journal of Nutrition 2003; 133: 3911S-3926S. 
